\title{
Effect of Foliar Application of Micronutrients and PGR's on Yield and Growth Characteristics of Guava (Psidium guajava L.) cv. Banarasi
}

\author{
M. Thiruppathi* \\ Department of Horticulture, Faculty of Agriculture, Annamalai University, \\ Annamalai Nagar- 608002, India \\ *Corresponding author
}

\begin{abstract}
A B S T R A C T
Keywords

$\mathrm{ZnSo}_{4}$, Borax, $\mathrm{GA}_{3}$, Guava and Growth characters

Article Info

Accepted:

15 July 2020

Available Online:

10 August 2020

An experiment was conducted in 12 year old plants field at Dharmapuri (Tamil Nadu) during the year 2019-20. To studies the effect of foliar application of micronutrients and PGR's on yield and growth characteristics of guava (Psidium guajava L.) cv. Banarasi. The experiment was laid out Randomized Block Design with ten treatments and replicated thrice with a unit of one plant in each replication of a treatment. Different doses of $\left(\mathrm{ZnSo}_{4}\right)$ @ $0.25 \%, 0.5 \%$ and $0.75 \%$, Borax @ 0.2\%, 0.4\% and 0.6\% and $\mathrm{GA}_{3} @ 50$ ppm, 75ppm and 100ppm with control (water sprayed) were sprayed before flowering and after fruit set. The present study it can be concluded that the Borax $0.6 \%$ followed by $0.4 \%$ significantly increased the flowering per shoot (56.83), fruit set $(65.4 \%)$, fruit retention $(56.78 \%)$, fruit weight $(142.5 \mathrm{~g})$, fruit length $(6.43 \mathrm{~cm})$, fruit width $(6.31 \mathrm{~cm})$ and fruit yield $(65.13$ $\mathrm{kg} / \mathrm{plant})$.
\end{abstract}

\section{Introduction}

Guava (Psidium guajava L.) belongs to family Myrtaceae is one of the important tropical and sub-tropical fruit of India. It is also known as "apple of tropics" and poor man's apple. Its nutritive values are very high, therefore, considered an ideal fruit for nutritional security and one of the cheapest and good source of vitamin 'C' (260 mg $/ 100 \mathrm{~g}$ ). It has been in cultivation in India since 17 th century and has originated in tropical America perhaps from Mexico to Peru and introduced in India by Portuguese. The total cultivated area of guava in India is 276 thousand hectares with an annual production of 4236 thousand MT (NHB 2018-19).Guava is hardy fruit plant which can be grown in poor alkaline or poorly drained soils. It gives ripen fruits mainly in two seasons of rains and winter. The rainy season crop is rough, insipid, poor in quality and less nutritive, whereas winter season crop is superior in quality having long storage life and fetches more price in the market (Rathore and Singh, 1976). Guava fruit is considered as one of the delicious and luscious fruit. It is also good source of pectin $(0.78 \%)$ and growth regulators and micronutrients play a vital role in growth and development of fruit trees and very effective in manipulating cropping season, improving fruit set, fruit retention and 
quality of guava fruits. Being perishable nature of ripe fruit, it is essential to improve the quality of guava fruits which may be helpful in prolongation of shelf life of fruits. Several research workers have observed certain pre-harvest treatments which helped in improving the quality of fruits at harvest and enhanced the storage life by influencing the post-harvest changes (Chaitanya et al., 1997).

\section{Materials and Methods}

12-year-old guava plants were taken for the investigation Effect of foliar application of micro nutrients and plant growth regulators on yield and growth characters. Twelve years old uniform guava plants planted at $6 \times 6 \mathrm{~m}$ space were selected for investigation. Nutrients application and other orchard management practices were followed as per recommended package of practices for guava plants. First spraying of micro nutrients and plant growth regulators were done before flowering (third week of August) and second after fruit set (last week of September) during 2019-20.Thus there were total ten treatments including (to water spray), $\mathrm{T}_{1} \mathrm{ZnSo}_{4} @ 0.25 \%$, $\mathrm{T}_{2} \mathrm{ZnSo}_{4} @ 0.5 \%, \quad \mathrm{~T}_{3} \mathrm{ZnSo}_{4} @ 0.75 \%$, T 4 Borax @ 0.2\%, T5 Borax @ 0.4\%, T 6 Borax @ 0.6\%,T 7 GA3 @ 50ppm, T8 GA3 @ 75 ppm, T9GA3 @ 100 ppm. The experiments was laid out in Randomized Block Design and replicated thrice taking a single tree as a unit. At harvest, a representative. Sample of twenty-five greenish yellow color mature fruits were taken randomly from three trees of each treatment and the observations on various physical attributes were recorded. Analysis of variance (one way classified data) for each parameter was performed using 'DISAAT' software. The data collected on different crop characters were analyzed statistically in randomized block design as suggested by Panse and Sukhatme (1985).The significance of different sources of variation was tested by error mean square by Fischer-
Snedecor's ' $F$ ' test at probability level of 5 percent $(\mathrm{p}=0.05)$.

\section{Results and Discussion}

\section{Effect on flowering, Fruit set and fruit retention}

It has been observed that $0.6 \%$ borax was most effective in increasing flowering per shoot (56.83), fruit setting $(65.40 \%)$ and fruit retention $(56.78 \%)$ followed by $0.4 \%$ of borax (Table 1). The increase in yield might due to direct or indirect involvement of micronutrients in photosynthesis, fruit setting, retention, reduction in drop as well as growth and development of fruits caused by foliar sprays of zinc and boron (Abhijith et al., 2018). Increasing levels of borax spray also increased the number of flowers per shoot, fruit set and fruit retention percentage with upto highest level of $0.6 \%$ borax solution spray but margin of increase beyond $0.4 \%$ borax spray was not found significant on flowers per shoot and fruit set percentage. However fruit set and fruit retention percentage was recorded on par each other with treatment $T_{5}$ and $T_{6}$ solution spray. It might be due to the reason that these nutrients play an important role in translocation of carbohydrates and in auxin synthesis to the sink and increase pollen viability and fertilization (Dewanshu et al., 2017). These results are in accordance to the findings of Raj Kumar et al., (2010), Panwar et al., 1995) and in litchi (Babu and Singh, 2001).

\section{Effect on fruit length, width, weight and yield}

It has been observed that boron $0.6 \%$ spray increase fruit weight $(142.50 \mathrm{~g})$, length $(6.43 \mathrm{~cm})$ and width $(6.31 \mathrm{~cm})$ and fruit yield $(65.13 \mathrm{~kg} /$ plant $)$ of guava maximum fruit cultivar Banarasi, it's treatment $\mathrm{T}_{6}$ and $\mathrm{T}_{5}$ on par with each other (Table 2). This increase in 
length and breadth of guava fruit may be due to the mineral nutrients specially boron appears to have direct role in hastening the process of cell division and cell elongation due to which size and weight would have improved. The increase in fruit weight may be due to the rapid increase in the size of cells and the increase in the fruit yield was due to the accumulation of sugars and other soluble solids in the fruits (Sukhjitkaur, 2017).

Table.1 Effect of foliar application of micronutrients and PGR's on flowering and fruiting behavior of guava

\begin{tabular}{|c|c|c|c|}
\hline Treatments & $\begin{array}{c}\text { Flowering } \\
\text { per shoot }\end{array}$ & $\begin{array}{c}\text { Fruit set } \\
(\%)\end{array}$ & $\begin{array}{c}\text { Fruit } \\
\text { retention }(\%)\end{array}$ \\
\hline $\mathrm{T}_{1}-\mathrm{ZnSo}_{4} @ 0.25 \%$ & 53.55 & 54.95 & 46.20 \\
\hline $\mathrm{T}_{2} . \mathrm{ZnSo}_{4} @ \mathbf{0 . 5 0 \%}$ & 55.64 & 60.17 & 52.37 \\
\hline $\mathrm{T}_{3}-\mathrm{ZnSo}_{4} @ 0.75 \%$ & 56.15 & 61.62 & 54.15 \\
\hline $\mathrm{T}_{4}$ - Borax @ 0.2\% & 54.61 & 58.03 & 49.03 \\
\hline $\mathrm{T}_{5}$ - Borax @ 0.4\% & 56.61 & 63.15 & 55.95 \\
\hline $\mathrm{T}_{6}-$ Borax @ 0.6\% & 56.83 & 65.40 & 56.78 \\
\hline $\mathbf{T}_{7}-\mathbf{G A}_{3} @ 50 \mathrm{ppm}$ & 53.10 & 53.46 & 44.62 \\
\hline$T_{8}-G_{3} @ 75$ ppm & 54.10 & 56.43 & 48.17 \\
\hline$T_{9}-G_{A_{3}} @ 100$ ppm & 55.13 & 59.60 & 50.73 \\
\hline$T_{10}$ - Control & 52.71 & 51.10 & 41.38 \\
\hline S.Ed & 1.02 & 1.10 & 0.94 \\
\hline CD at $5 \%$ & 2.14 & 2.28 & 1.96 \\
\hline
\end{tabular}

Table.2 Effect of foliar application of micronutrients and PGR's on fruit characters and yield of guava

\begin{tabular}{|c|c|c|c|c|c|}
\hline Treatments & $\begin{array}{c}\text { Length of } \\
\text { fruit } \\
\text { (cm) }\end{array}$ & $\begin{array}{c}\text { Width of } \\
\text { fruit } \\
\text { (cm) }\end{array}$ & $\begin{array}{c}\text { Fruit } \\
\text { weight } \\
\text { (g) }\end{array}$ & $\begin{array}{c}\text { Fruit } \\
\text { yield/plant } \\
(\mathbf{k g})\end{array}$ & $\begin{array}{c}\text { Fruit } \\
\text { yield/ha } \\
\text { (tone) }\end{array}$ \\
\hline $\mathrm{T}_{1}-\mathrm{ZnSo}_{4} @ 0.25 \%$ & 5.97 & 5.74 & 130.57 & 55.00 & 15.29 \\
\hline $\mathrm{T}_{2 .} \mathrm{ZnSo}_{4} @ 0.50 \%$ & 6.27 & 6.11 & 138.11 & 61.58 & 17.20 \\
\hline $\mathrm{T}_{3}-\mathrm{ZnSo}_{4} @ 0.75 \%$ & 6.33 & 6.20 & 139.94 & 63.13 & 17.55 \\
\hline$T_{4}$ - Borax @ 0.2\% & 6.14 & 5.93 & 134.35 & 58.43 & 16.24 \\
\hline$T_{5}$ - Borax @ 0.4\% & 6.40 & 6.28 & 141.77 & 64.58 & 17.95 \\
\hline$T_{6}$ - Borax @ 0.6\% & 6.43 & 6.31 & 142.50 & 65.13 & 18.11 \\
\hline $\mathbf{T}_{7}-\mathbf{G A} \mathbf{A}_{3} @ 50$ ppm & 5.90 & 5.68 & 128.63 & 53.70 & 14.93 \\
\hline $\mathrm{T}_{8^{-}} \mathbf{G A}_{3} @ 75$ ppm & 6.08 & 5.82 & 132.42 & 56.68 & 15.76 \\
\hline$T_{9}-G_{3} @ 100$ ppm & 6.21 & 6.02 & 136.28 & 60.08 & 16.70 \\
\hline $\mathbf{T}_{10^{-}}$Control & 5.79 & 5.60 & 125.94 & 52.38 & 14.56 \\
\hline S.Ed & 0.11 & 0.11 & 2.51 & 1.10 & 0.31 \\
\hline CD at $5 \%$ & 0.23 & 0.23 & 5.27 & 2.31 & 0.64 \\
\hline
\end{tabular}


The increase in the size of fruits was due to the rapid fruit development and the greater mobilization of food materials from the site of production to storage organs under the influence of applied nutrients. Kumar et al., (2004) advocated that foliar application of borax $(0.4$ and $0.6 \%)$ significantly improve fruit length, diameter and fruit weight in litchi cv. Dehradun and Singh et al., (2004) found that foliar spray of boric acid $(0.4 \%)$ considerably increased size and weight of guava fruit in comparison to control. Banik et al., (1997) found that foliar application borax $0.4 \%$ significantly increased length, width and weight in mango cv. Fazli.

Fruit length, width, weight, volume and yield per plant were recorded significantly highest values with highest level of $0.6 \%$ borax solution spray. It is believed that boron improves the physiological activities of plant which might have improved size, weight, volume of fruits and ultimately higher fruit yield per plant. Besides, fruit yield per plant is also attributed to fruit retention percentage. Thus, fruit yield per plant seems to be the combined effect on single fruit weight and number of fruits per plant. The application of zinc and boron might have caused rapid synthesis of protein and translocation of carbohydrate which ultimately led to increase in fruit weight which is directly correlated with total yield (Singh et al., 2012). These results corroborate with the findings of Prasad et al., (2005). Similar results have been reported in aonla (Ram et al., 1977; Dashora et al., 2005).

In conclusion the result of present study may be concluded that foliar spray of Borax @ 0.4 $0.6 \%$ solution on guava plants twice i.e. once before flowering (third week of August) and again after fruit setting (last week of September) are beneficial to found to be most effective for overall increment of flowering, fruit set, fruit retention, yield and quality attributes.

\section{References}

Anonymous. NHB, Database, Gurgaon, Haryana, 2018-19.

Babu, N. and Singh, A. R., 2001, Effect of foliar application of boron, zinc and copper on chemical characterization of litchi fruits. Bioved., 12 (1/2): 45-48.

Banik BC, Sen SK, Bose TK. Effect of zinc, iron and boron in combination with urea on growth, flowering, fruiting and quality of mango cv. Fazli. Environ. Eco-B. C.K.V., Kalyani. 1997; 15(I):122-125.

Chaitanya, C.G., Kumar G., Rana, B.L. and Mathew, A.K. (1997). Effect of foliar application of zinc and boron on yield and quality of guava Cv. L-49. Haryana Journal of Horticulture Science, 26 (1-2): 78-80.

Dashora, L. K., Lakhawant, S. S. and Aravindakshna, K., 2005, Effect of foliar spray of zinc and boron on yield and quality of aonla. National seminar on commercialization of Horticulture in non-tradition Areas, Bikaner, Feb. 85: 5-6.

Dewanshu B, S. tomar, Singh J.P. and Maurya, J.K., (2017), Effect of foliar application of zinc and boron on fruit growth, yield and quality of winter season guava (Psidium guajava L.). International Journal of Current Microbial Applied Science 6(9): 15251529.

Kumar S, Kumar S, Verma DK. Effect of micro-nutrients and NAA on yield and quality of litchi (Litchi chinensis Garentn) Sonn cv. Dehradun. Abst in Proc. of International Seminar on Rec. Trend in Hi-Tech Horticulture and PHT, originated by C.S.A.U.A. \& T., Kanpur. 2004; 4-6:193.

Panse, V.G., and Sukhatme, P.V. (1985). Statistical Methods for Agriculture Workers. ICAR, New Delhi. 
Panwar, R. D., Saini, R. S., Kaushik, R. A. and Yamdagni, R., 1995, Effect of micronutrients on fruit retention, yield and quality of aonla $c v$. Banarasi under rainfed condition. Haryana Journal of Horticultural Science, 22 (1-2): 250-251.

Prasad, B., Das, S., Chatterjree, D. and Singh, U.P. (2005). Effect of foliar application of urea, zinc and boron on yield of guava. Journal of Applied Biology, 15 (1): 44-47.

Rajkumar Tiwari, J.P. and ShantLal, (2010). Effect of foliar application of zinc and boron on fruit yield and quality of winter season guava (Psidium guajava

L.) Cv. Pant Prabhat. Annals of Agricultural Biology Research, 19 (1): 105-108.

Ram, S., Dwivedi, J. S. and Bist, L. D., 1977, Internal fruit necrosis in aonla (Emblica officinalis Gaertn.). Progresssive Horticulture, 8 (3): 5-12.

Rathore, D.S., and Singh, R.N. 19976. Yield pattern in tree cropping patter of guava (Psidium guajava L.). Indian Journal of Horticulture, 33: 7-13.

Singh R, Chaturvedi OP, Singh R. Effect of pre-harvest spray of zinc, boron and calcium on the physico-chemical quality of guava fruit (Psidium guajava L.). International Seminar on Recent Trend on Hi-Tech Horticulture and P.H.T., Kanpur, February. 2004; 4-6:2004-204.

Singh, P. C., Gangwar, R. S. and Singh, V. K., 2012, Effect of micronutrients spray on fruit drop, fruit quality and yield of aonla $c v$. Banarasi. Hortultural Flora Research Spectrum, 1(1): 73-76.

Snedecor, G. W. and W.G. Cochran (1968). Statistical Methods. Ox ford and IBH Pub. CO. Kolkata. 469p.

Sukhjit Kaur, (2017), Effect of micronutrients and plant growth regulators on fruit set, fruit retention, yield and quality attributes in litchi cultivar Dehradun. Chemical Science Review lettters 6(22), 982-986.

Abhijith, Y.C., J. Dinakara Adiga, H. Kishor and C. Sindhu, (2018), Effect of micronutrients on yield and quality of aonla (Emblica officinalis Gaertn.) cv. NA-7. International Journal of Current Microbiology and Applied Science 7(3): 140-145.

\section{How to cite this article:}

Thiruppathi, M. 2020. Effect of Foliar Application of Micronutrients and PGR's on Yield and Growth Characteristics of Guava (Psidium guajava L.) cv. Banarasi Int.J.Curr.Microbiol.App.Sci. 9(08): 1486-1490. doi: https://doi.org/10.20546/ijcmas.2020.908.171 